\title{
PERAN STANDARDISASI DAN PENILAIAN KESESUAIAN (SPK) DALAM UPAYA MENDUKUNG PERCEPATAN PEMULIHAN PANDEMI COVID-19
}

\author{
The Role of Standardization and Conformity Assessment For the Supporting of \\ Acceleration to Recovery of Pandemi COVID-19
}

\author{
Bambang Prasetya \\ Badan Standardisasi Nasional Puspiptek Gd.420-430 \\ E-mail: bambang.prasetya@bsn.go.id
}

\begin{abstract}
Abstrak
Pandemi COVID-19 yang melanda di berbagai belahan dunia telah mendorong terjadinya perubahan di berbagai aspek kehidupan baik sosial, ekonomi dan juga tata kelola di organisasi pemerintahan, organisasi swasta dan dunia usaha. Perubahan ini menuntut langkah-langkah tepat untuk menangani secara langsung terhadap kesehatan masyarakat baik preventif maupun penyembuhan. Sejalan dengan itu juga dilakukan langkah-langkah untuk pemulihan dari dampak yang diakibatkan oleh pandemi COVID-19. Dengan menggunakan metode studi literatur dari berbagai sumber dan pengamatan langsung, dalam makalah ini disusun dengan tujuan untuk memberikan gambaran yang komprehensif tentang pandemi COVID-19 dan dampaknya, kebijakan pemerintah dalam menangangi pandemi, peran standardisasi dan penilaian kesesuaian dalam mendukung kebijakan pemerintah dan pelayanan masyarakat. Sebagai pembanding (bench-marking), juga diuraikan tentang penanganan pandemi dan peran standardisasi dalam persepsi global. Untuk menggambarkan peran standardisasi secara nasional, diuraikan tentang peran pengembangan/perumusan standar dan penerapannya, peran akreditasi dan metrologi (standar nasional satuan ukuran) dalam meningkatan mutu hasil uji laboratorium medis. Lebih lanjut juga dibahas tentang program akselerasi layanan jasa. Untuk antisipasi kebutuhan standardisasi di masa mendatang setelah melewati masa krisis pandemi, lebih jauh diuraikan tentang prioritasi pengembangan standar untuk mendukung kemandirian dan daya saingnasional.
\end{abstract}

Kata kunci: pandemi COVID-19, trend global, standardisasi, penilaian kesesuaian, kemandirian nasional

\begin{abstract}
The COVID-19 pandemic that has hit various parts of the world has led to changes in various aspects of life, social, economic and also governance in many type of organization such as government organizations, private organizations and the business. To overcome this situation, a number of appropriate activities is needed to directly address the various problems in public health, either both preventive and curative. In line with that, activities have also been taken to recover from the impact caused by the COVID-19 pandemic. Using the method of literature study from various sources and direct observation, this paper is prepared with the aim of providing a comprehensive situation of the COVID-19 pandemic and its impacts, government policies in dealing with pandemics, the role of standardization and conformity assessment in supporting government policies and community services. As a comparison (bench-marking), it also describes the handling of the pandemic and the role of standardization in global perceptions. To illustrate the role of standardization at national level, will be reported the role of developing/ formulating standards and their application, the role of accreditation and metrology (national standard units of measure) in improving the quality of medical laboratory test results. Furthermore, it is also discussed about the service acceleration programs. To anticipate the need for standardization in the future after passing the pandemic crisis period, the need of the prioritization of standard development to support national independence and competitiveness is also elaborated.
\end{abstract}

Kata kunci: COVID-19 pandemic, global trends, standardization, conformity assessment, national independence 


\section{PENDAHULUAN}

Wabah virus corona atau dikenal dengan nama COVID-19 (Coronavirus Disease 2019) yang berawal dari Wuhan, Tiongkok telah menjadi permasalahan global dalam waktu yang sangat cepat. Dalam jangka waktu 1-2 bulan dimulai pada akhir tahun 2019, virus COVID-19 ini telah menyebar dan merubah tatanan kehidupan di hampir seluruh negara-negara di dunia. Pandemi COVID-19 yang menyebar secara cepat dan telah mengancam kesehatan publik dan sistem yang berhubungan dengan kehidupan. Hal ini mendorong berbagai negara untuk mengambil berbagai langkah pencegahan yang ekstrim cepat dan tepat. Salah satu langkah kebijakan yang diambil hampir semua negara adalah pelarangan atau pembatasan perjalanan (travel ban/restriction), penutupan perbatasan, serta memperketat lalu lintas manusia antar wilayah/ negara.

Pandemi COVID-19 juga telah menyebabkan terjadinya berbagai perubahan perilaku masyarakat, tatakelola organisasi baik di pemerintahan, dunia usaha mauppun organisasi lain. Perubahan kehidupan sosial, ekonomi, budaya dan lingkungan terjadi untuk menyesuaikan keadaan. Efek yang langsung yang dirasakan adalah menyangkut kesehatan manusia dan kemudian berimbas kepada ketahanan ekonomi di level negara, pelaku usaha dan keluarga. Hal ini semakinterasa untuk masyarakat lapisan bawah. Terganggunya nadi perekonomian di berbagai sektor logistik, produksi, mobilisasi dan distribusi menyebabkan perubahan pola konsumsi, penawaran dan permintaan. Dampak lain yang juga terasakan adalah meningkatkan pengangguran sebagai akibat pemutusan hubungan kerja (PHK) dari perusahaan yang tidak mampu bertahan.

Beberapa sektor terdampak langsung dari kejadian ini seperti sektor transportasi, perdagangan, serta pariwisata. Sektor informal juga diperkirakan akan terdampak signifikan dari COVID-19 ini. Gangguan pada aktivitas ekonomi secara mendalam dapat berdampak pada profitabilitas, solvabilitasi, serta keberlangsungan usaha.

Pemerintah melakukan berbagai langkah penanganan COVID-19 antara lain dengan melakukan akselerasi penanganan COVID-19 dan pemberian stimulus yang ekstensif untuk menangani COVID-19 dan mencegah krisis ekonomi. Perkembangan yang sangat dinamis dan sulit diprediksi memerlukan koordinasi dan sinergi yang lebih intensif dan berkualitas dari semua komponen. Standardisasi sebagai bagian sistem manajeme nasional mendapat tantangan baru sejalan dengan program- program yang sedang dijalankan pemerintah baik dalam rangka penanganan pandemi yang terkait denganmasalah kesehatan dan sarana pendukungnya. Kemudian pada kegiatan dalam upaya pemulihan dampak pandemi dan kegiatan pasca pandemi yang terkait dengan penguatan daya saing nasional dan kemandirian nasional.

\section{TINJAUAN PUSTAKA}

Pandemi virus corona oleh organisai kesehatan dunia WHO (World Health Organization) diberi nama Corona-virus-disease 2019 (COVID-19). Virus ini menurut ICTV (the International Committee on Taxonomy of Viruses) dikatagorikan "Severe acute respiratory syndrome coronavirus 2 (SARS-CoV-2). Virus ini tergolong dalam ordo Nidovirales, famili Coronaviridae, subfamili Ort- hocoronavirinae yang di dalamnya terdiri atas 4 jenis yaitu Alphacoronavirus, Betacoronavirus, Gammacoronavirus dan Deltacoronavirus. Gambar 1 memberikan ilustrasi penggolongan gen virus yang dikaitkan dengan agen pembawa penularan (Dhama et al. 2020).

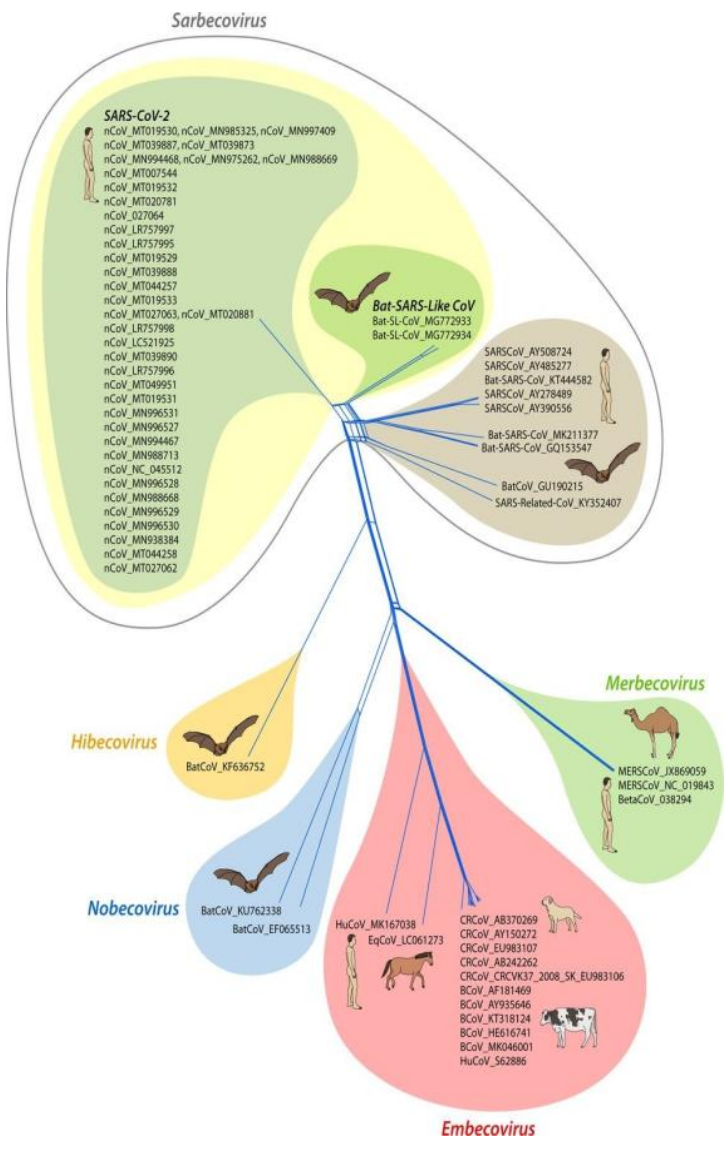

Gambar 1. Diagram klasifikasi gen virus corona dan pembawa penularannya (Dharma et al. 2020). 
Merebaknya pandemi Covid-19 yang begitu cepat memberikan indikasi bahwa karakteristik dan dinamika Virus Corona berbeda den- gan virus sebelumnya. Hal lain yang perlu di- cermati adalah bahwa Indonesia sebagai negara tropis basah (tropical humid) di mana dapat menjadi tempat hidup (habitat) yang baik untuk berbagai mikroorganime termasuk virus dan varian- variannya. Kombinasi kondisi geografi, kelembaban, suhu udara dapat menimbulkan peluang terjadinya variasi iklim mikro (microclimate). Ad- anya periodesasi dan intensifitas sinar matahari yang relatif tinggi dapat menyebabkan terjadinya mutasi virus sehingga peluang munculnya berbagai mutan atau varian baru sangat besar (Wang et al. 2020). Hal ini penting diketahui untuk memilih strategi yang tepat dengan memper timbangkan risiko (risk based thinking of stratregy).

Meskipun setiap kejadian pandemi virus mempunyai karateristik yang berbeda, misalnya pandemi flu tahun 1918 dan pandemi flu burung SARS pada tahun 2003, namun secara umum pengendaliannya diklasifikasikan ke dalam beberapa tindakan yang masing masing mempunyai tingkat risiko yang berbeda beda. Seperti digambarkan pada gambar 2, hierarki pengendalian pandemi dapat dibagi menjadi 5 tingkatan (Avra 2018). Beberapa negara melakukan yang semacam ini dengan konten yang berbeda-beda. Pada level pertama tindakan yang dilakukan adalah penggunaan perlindungan diri (Personal protective equipment, $P P E$ ). Pada level ini penggunakan masker, cuci tangan dan menjaga jarak menjadi kunci penting dan ini merupakan tahap awal pencegahan. Level berikutnya adalah pengendalian dengan pengaturan administrasi (administration control). Pada tahap di di Indonesia misalnya pemberlakukan pengaturan pembatasan pergerakan dan aktifitas orang seperti PSBB (pembatasan sosial berskala besar), pengaturan jam kantor (work from home, WFH dan work formoffice, WFO). Ketiga, pada level enginering controls, pengendalian dilakukan dengan penyediaan infrastrukur seperti fasilitas untuk isolasi untuk orang yang terinfeksi dan penyediaan fasilitas pengobatan. Pada level empat dilakukan substitusi (substitution) yaitu tindakan pemindahan patogen berbahaya (hazard) dan level ke lima adalah tindakan eliminasi (elimination) yang bertujuan untuk menghilangkan patogen. Untuk tindakan level 4 dan 5 ini memerlukan kajian yang lebih komprehensif dan untuk COVID-19 belum banyak publikasi yang melaporkan tindakan ini.

\section{Hierarchy of controls}
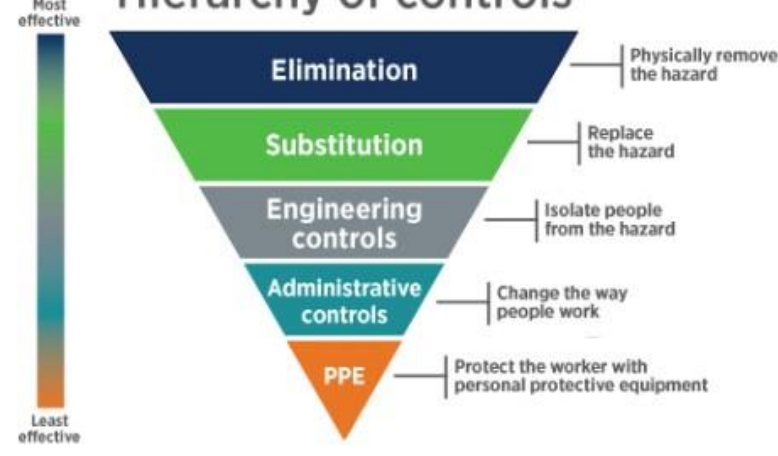

Gambar 2. Hierarki pengendalian patogen/bahan berbahya (Avma, 2020).

Pemerintah melakukan tindakan pemulihan pandemi dengan tiga kelompok yaitu enabling environment, perbaikan produktifitas (productivity improvement) dan pemberlakukan undang-undang Cipta Lapangan Kerja. Pada kegiatan pertama difokuskan pada perbaikan iklim usaha, peningkatan daya saing, serta ketahanan ekonomi melalui perbaikan di sektor pangan, energi dan infrastruktur. Untuk peningkatan produktifitas difokuskan pada perbaikan sektor-sektor usaha yang berpotensi menopang kinerja perekonomian nasional, mencakup revitalisasi manufaktur, pembangunan pariwisata, serta pemberdayaan dan formalisasi usaha mikro, kecil dan menengah. Sebagai upaya untuk perbaikan regulasi pemberlakukan UU Cipta Lapangan Kerja menjadi salah satu wahana yang untuk mengharmonisasikan berbagai peraturan perundangan. Dalam ini berbagai perijinan dipermudah. Standardisasi dan penilaian kesuaian memegang peran penting dalam harmonisasi ini. Salah yang sangat kunci upaya harmonisasi regulasi adalah klasterisasi jenis usaha penyedia barang dan jasa berdasarkan tingkat risiko. Semakin besar risiko maka regulasi dilakukan dengan ketat misalnya seperti inspeksi, sertifikasi oleh pihak ketiga, ijin edar dst, sedangkan untuk produk yang berisiko rendah hanya diperlukan pernyataan diri (self declare) dan registrasi.

Menurut UNIDO (2020) peran standardrdisasi sangat penting dalam menghadapi pandemi COVID-19 ini. Seperti digambarkan pada Tabel 1. Standardisasi termasuk bagian dari infrastuktur mutu membantu mengurangi dampak negatif dari krisis pandemi dan memastikan penyediaan layanan penting. Infrastruktur mutu, di mana standardisasi dan penilaian kesesuaian di dalamnya berfungsi untuk memastikan kebutuhan standar yang relevan, pengukuran yang akurat (metrologi), memberikan jaminan hasil test yang handal melalui akreditasi. 
Standar memastikan bahwa teknologi yang digunakan dalam penanganan pasien aman dan semua pengguna terlindungi.

Tabel 1 Peran Standardisasi dalam Menghadapi Covid-19 menurut UNIDO (2020)

\begin{tabular}{|c|c|c|c|c|c|}
\hline Policy & Standards & Accreditation & Metrology & $\begin{array}{l}\text { Conformity } \\
\text { Assessment }\end{array}$ & Enterprises \\
\hline $\begin{array}{l}\text { Quality Policy } \\
\text { Laboratory } \\
\text { Policy }\end{array}$ & $\begin{array}{l}\text { Medical } \\
\text { equipment/ } \\
\text { protecilive } \\
\text { gear } \\
\text { (Medical) } \\
\text { laboralory } \\
\text { standards } \\
\text { Business } \\
\text { continuity / } \\
\text { emergency } \\
\text { management } \\
\text { Qualily control } \\
\text { techniques } \\
\text { Health, safely } \\
\text { \& hygiene } \\
\text { Sanitation and } \\
\text { waste } \\
\text { management }\end{array}$ & $\begin{array}{l}\text { Attestation of } \\
\text { technical } \\
\text { competence } \\
\text { International } \\
\text { Imutual } \\
\text { recognition }\end{array}$ & $\begin{array}{l}\text { Accurate } \\
\text { measurement } \\
\text { for reliable } \\
\text { testing } \\
\text { Quality and } \\
\text { accuracy of } \\
\text { laboratory } \\
\text { tests }\end{array}$ & $\begin{array}{l}\text { Health care } \\
\text { facilities and } \\
\text { testing } \\
\text { laboratories } \\
\text { Quality control } \\
\text { of medical } \\
\text { supplies } \\
\text { Medical } \\
\text { testing for } \\
\text { CoviD-19 } \\
\text { Development } \\
\text { of new } \\
\text { medication/ } \\
\text { vaccines } \\
\text { Market } \\
\text { surveillance } \\
\text { and } \\
\text { inspection }\end{array}$ & $\begin{array}{l}\text { Shifit to } \\
\text { produce } \\
\text { medical } \\
\text { equipment/ } \\
\text { protective } \\
\text { gear } \\
\text { Business } \\
\text { continuity } \\
\text { Enhanced } \\
\text { sanily } \\
\text { protocols } \\
\text { Avoid } \\
\text { disruption o } \\
\text { essential } \\
\text { inputs to } \\
\text { global value } \\
\text { chains }\end{array}$ \\
\hline
\end{tabular}

Dikaitkan dengan sustainable development goals (SDGs) sebagai acuan dan juga sering dijadikan indikator yang holistik. SDGs merupakan agenda global bersama yang semua negara telah berkomitmen untuk melaksanakan. Adanya pandemi ini menurut UNIDO dampak yang sangat signifikan adalah terkait dengan SDG 2 (penanggulangan kelaparan); SDG3 (kehidupan yang sehat dan kesejahteran untuk semua); SDG 8 (pertumbuhan ekonomi dan lapangan kerja);

SDG 9 (pembangunan infrastruktur, industri dan inovasi); SDG 12 (konsumsi dan produksi yang bertanggung jawab) dan SDG 17 (kemitraan untuk mencapai semua tujuan SDGs). Secara rinci dampak pandemi dan peran standardisasi dilukiskan pada Gambar 3. (UNIDO 2020, Lee et. al, 2020).

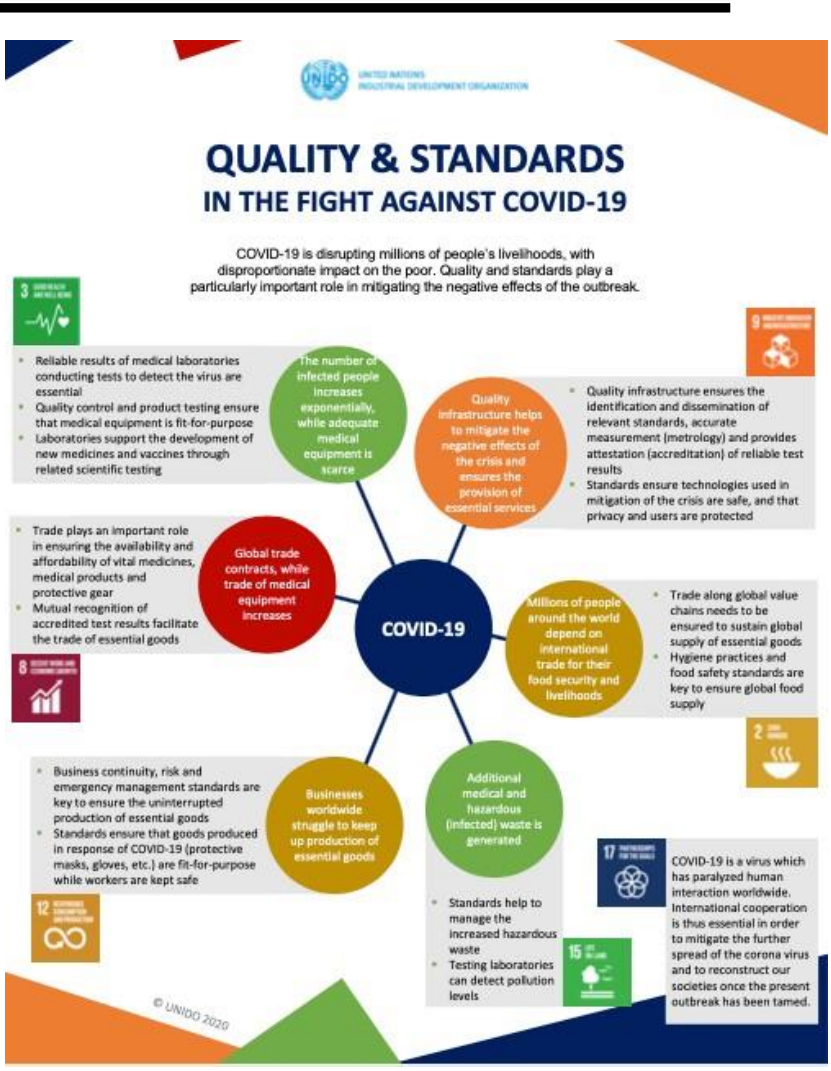

Gambar 3. Dampak pandemi terhadap SGDs dan peran standar dalam manajemenkrisis pandemi.

Menurut ITC (International Trade Center) dalam laporannya "Standards support for small busi- nesses during COVID-19", 26 May 2020) menggambarkan peran standar dalam membantu kesiapan dunia usaha termasuk UMKM menghadapi krisis. Diantaranya adalah adalah ISO 22301:2019; ISO 22313:2020; ISO/TS 22318:2015; ISO 22320:2018; ISO 22316:2017; ISO 31000:2018; ISO 56002:2019; ISO 45001:2018; ISO 22000:2018; ISO 9001:2015;

\section{METODE PENELITIAN}

Metode yang digunakan berupa studi literatur dan analisa deskriptif, Sumber literatur terkait dengan perkembangan terakhir COVID19 dan dampak pandemi di tingkat nasional dan global. Strategi dan kebijakan pemerintah dalam menangani pandemi termasuk kebijakan pemulian ekonomi. Peran standardisasi dan penilaian kesesuian dalam menghadapi COVID-19 didasarkan trend global dan beberapa rekomendasi dari UNIDO. Analisa dilakukan dengan melihat trend dan target yang dicapai. Peran standardisasi dan penilaian kesesuaian untuk penguatan daya saing dan kemandirian dianalisa berdasarkan testimoni beberapa role model dan pakar. Penanganan dampak jangka panjang dianalisa dan 
direkomendasikan pada prioritas arah pengembangan standar dan faktor penting yang berpengaruh yang harus diperhatikan.

\section{HASIL DAN PEMBAHASAN}

\section{Peran Standardisasi dalam Penanganan pandemi}

Standardisasi dalam menangangani pandemi memegang peranan penting, khususnya untuk menjamin keamanan, mutu dan ketelusuran. Standar produk khususnya peralatan medis antara lain berupa perangkat pelindung pernapasan, peralatan pelindung tubuh seperti sarung tangan medis, masker wajah medis, pelindung mata pribadi dan lain lain. Pengembangan standar baru diperlukan untuk menyesuaikan dengan kebutuhan. Di samping pemanfaatan standar yang ada, masih diperlukan pengem- bangan standar baru yang diperoleh dengan mengadposi standar internasional maupun den- gan proses modifikasi standar international yang disesuaikan dengan kondisi Indonesai.

Dalam pengembangan standar beberapa hal yang patut dipertimbangkan adalah bagaimana sistem pengakuan (recogniton) dan keberterimaan (acceptance) standar antar negara. Penerimaan kesetaraan standar di antara mitra dagang (Busines to Busines) dinilai penting untuk memobilisasi permintaan peralatan medis yang melonjak dalam waktu singkat.

Saat ini ketersedian SNI terkait dengan peralatan kesehatan (medical devices) dan sanitasi sebagai berikut: pakaian pelindung 31 SNI, handsanitizer $14 \mathrm{SNI}$, sarung tangan medis $13 \mathrm{SNI}$, ventilator $13 \mathrm{SNI}$, pelindung mata $6 \mathrm{SNI}$, pelindung pernafasan $4 \mathrm{SNI}$, masker medis $4 \mathrm{SNI}$ dan sarung tangan pelindung 3SNI.

Untuk mendukung sistem manajemen laboratorium, telah tersedia standar manajemen laboratorium medis yaitu SNI ISO 15189, ISO 22367 dan SNI ISO 14971. Standar ini penting untuk mengevaluasi keamanan dan hasil tes diagnostik yang valid virus corona SARS-COV2. Untuk mendukung kegiatan pengujian laboratorium, saat ini sudah lebih dari 1700 laboratorium yang menerapakan SNI ISO 17025. Standardissi laboratorium penguji diperlukan untuk memastikan bahwa pengujian produk untuk peralatan medis dilakukan dengan benar dan memberikan hasil yang handal sehingga dapat merespons pandemi COVID-19 secara efektif dan tepat sasaran. Untuk lab-lab tertentu yang bekerja dengan benda biologis patogen penerapan sistem manajemen biorisiko laboratorium SNI ISO
35001:2019 menjadi sangat penting khususnya untuk menjamin keamanan petugas laboratorium yang berkeja dengan COVID-19

Untuk mendukung penanganan pandemi tindakan preventif di suatu industri atau organisasi dapat menerapkan sistem manajemen kesehatan dan keselamatan kerja, SNI ISO 45001. Penerapaan standar ini sangat penting untuk menjaga kesehatan dan keselamatan kerja, mengurangi risiko di tempat kerja, dan menciptakan kondisi kerja lebih aman terhadap penularan COVID-19.

Untuk mendukung industri pengolahan pangan penerapan sistem manajemen keamanan pangan berbasis pada SNI ISO 22000 dan HACCP (Hazard Analysis and Critical Control Points) menjadi kunci untuk menjamin keamanan pangan. Tidak kalah pentingnya dalam penanganan pandemi adalah penerapan standar sistem manajemen lingkungan SNI ISO 14000. Stan dar ini akan dijadikan sebagai wahana pengelolaan yang lebih baik terhadap limbah yang dihasilkan sebagai akibat peningkatan penggunaan peralatan pelindung sekali pakai seperti pakaian pelindung, sarung tangan sekali pakai, masker medis dan lain lain.

Selama pandemi diketahui banyak industri yang terdampak sebagai akibat menurunkannya aktifitas ekonomi. Untuk memperkuat daya tahan perusahaan penerapan standar manajemen risiko SNI ISO 31000 yang sdh lama dilakukan di banyak organisasi dan perusahaan dan terbukti mampu melewati krisis. Demikian pula di masa pandemi dan masa pemulihan penerapan standar ini cukup vital sebagai pedoman untuk desain, implementasi dan pemeliharaan manajemen risiko. Dengan kombinasi penerapan standar manajemen lain seperti SNI ISO 9001 yang cukup populer penerapannya di Indonesia maka daya tahan perusahan atau organiasi menjadi lebih sempurna. Dengan penerapan standar ini perusahaan lebih siapuntuk menghadapi dampak negatif dari krisis. Penguatan kinerja perusahaan di saat krisis juga dapat menggunakan standar untuk keamanan, ketahanan dan manajemen kelangsungan bisnis (misalnya ISO 22301, ISO 22395) dan manajemen darurat (misalnya ISO 22320, ISO 22316). Standar ini di beberapa negara telah terbukti memegang peranan penting dalam menghadapi pandemi COVID19. Penerapan lebih lanjut dari standar tersebut tidak saja penting dalam jangka pen- dek, tetapi juga untuk dalam jangka menengah dan panjang. 


\section{Peran Akreditasi dan Penilaianan Kesesuaian dalam penanganan pandemi}

Salah satu pilar penting dalam sistem penjaminan mutu nasional adalah akreditasi. Kegiatan akreditasi sangat penting dalam mendukung penerapan standar agar kesesuaian produk, jasa, proses dan manajemen dapat berjalan sesuai dengan persayaratan dan standar yang diterapkan. Komite Akreditasi Nasional (KAN) menjalankan fungsi untuk memberikan pengakuan/pengesahan formal atas integritas dan kopentensi Lembaga Penilaian Kesesuaian (LPK) untuk melakukan kegiatan penilaian kesesuaian. LPK yang dimaksud antara lain adalah laboratorium uji, lembaga sertifikasi, inspeksi, dan kalibrasi.

Proses akreditasi yang banyak dilakukan pada saat ini adalah untuk laboratorium uji dan kalibrasi. Hal ini dimaksudkan agar hasil pengujian laboratorium valid dan handal serta memenuhi standar yang dipersyaratkan. Akreditasi laboratorium juga memastikan bahwa sumber daya manusia yang berkerja di laboratorium kompeten. Demikian juga dengan manajemen yang profesional dan kompeten laboratorium mampu memberi layanan berbagai pengujian dan beberapa kebutuhan lain terkait dengan penanganan pandemi.

Selama pandemi ini banyak inovasi telah dihasilkan dari dalam negeri. Karena pada umum- nya merupakan produk baru, maka akreditasi lembaga sertifikasi produk dan laboratorium uji sangat diperlukan untuk menjamin keamanan produk dan juga meningkatkan kepercayaan kepada masyarakat terhadap produk inovasi dalam negeri.

Dalam kaitannya dengan pandemi COVID-19 secara global, akreditasi kepada LPK oleh lembaga akreditasi yang menjadi anggota organ- isasi internasional akreditasi sangat penting, karena untuk menjamin kompatibilitas penggu- nakan sertifikat yang secara globalnya sangat diperlukan pengakuannya. Hal ini ditujukan pula untuk memfasilitasi mobilisai antar negara pro- duk dan jasa terkait dengan peralatan medis, kit pengujian dan barang-barang untuk perlindungan pribadi. Kurangnya pengakuan terhadap laboratorium pengujian misalnya dapat menggagu kelancaran arus perdagangan.

Pengakuan sertifikat dari LPK di Indonesia secara international diperoleh melalui pengakuan KAN oleh organisasi international akreditasi ILAC (Intenational Laboratory Accreditation Cooperation), mengikuti skema MLA (mutual recognition arrangement) dan dari International Accreditation Forum (IAF) melalui skema MRA (multilateral recognition arrangement).

Selama pandemi LPK yang sudah mendapat akreditasi KAN antara lain 70 laboratorium dan klinik untuk SNI ISO 15189, 100 laboratorium penguji untuk SNI ISO 17025, 40 laboratorium kalibrasi untuk SNI ISO 17025, 5 Lab Penyelenggara Pemantapan Eksternal (PME Lab) untuk SNI ISO/IEC 17043, 2 lembaga Inspeksi untuk SNI/ISO/IEC 17020, 2 lembaga sertifikasi sistem manajemen alat kesehatan untuk SNI/ ISO/IEC 17021, dan 1 lembaga sertifikasi sistem manajemen biorisiko laboratorium untuk SNI ISO/IEC 17021).

\section{Peran Metrologi (SNSU) dalam penanganan pandemi}

$\begin{array}{ccc}\text { Dalam } & \begin{array}{c}\text { pemenuhan } \\ \text { suatu produk }\end{array} & \begin{array}{r}\text { kesesuaian } \\ \text { diperlukan }\end{array}\end{array}$ serangkaian pengujian sifat fisik, mekanik, biologis dan kimia sesuai dengan standar yang diinginkan. Metrologi memberikan jaminan pengukuran yang andal sebagai dasar penelitian ilmiah, pengembangan teknis, dan produksi.

Metrologi atau SNSU (Sistem Nasional Satuan Ukuran) diperlukan untuk mendukung laboratorium pengujian produk untuk memastikan bahwa barang, jasa, dan proses memenuhi persyaratan kualitas produk, lingkungan, kesehatan dan keselamatan, serta memenuhi kebutuhan dan harapan konsumen. Tingkat kesesuaian dengan persyaratan sangat ditentukan oleh tingkat akurasi alat uji yang harus tertelusur dengan sistem satuan ukuran internasional (BIPM) dapat meningkatkan pengakuan dan penerimaan se- cara internasional. Dengan demikian pengguna akan dapat memanfaatkannya untuk memperlu- as akses ke pasar global.

Dalam penangangan COVID-19, metrologi sangat penting karena pengukuran kimiawi dan biologis yang menuntut keakuratan tinggi dan memainkan peran penting dalam masa pandemi, khususnya standar bahan acuan (CRM). Hasil uji yang tertelusur akan menjadi basis data yang kompatibel untuk berbagai penggunaan hasil test sehingga dapat meningkatkan kepercayaan pada pengguna. Potensi kemungkinan adanya pemalsuan data yang terkada terjadi akan dapat dihindari.

Pemerintah dalam menangani kasus pandemi sangat membutuhkan alat ukur yang akurat dari hari ke hari seperti termometer, sphygmomanometer (pengukur tekanan darah), pengukur aliran oksigen (respirator), pengukur aliran cairan (obat) dan lain-lain. Semua hasil pengukuran harus dapat dipercaya dan dapat diandalkan. 
Untuk pengakuan international terhadap kemampuan metrologi nasional maka semua standar satuan ukuran nasional harus tertelusur ke organisasi internasional BIPM (International Bureau of Weights and Measures) yang berpusat di Paris. Posisi saat ini Indonesia sudah mendap- atkan pengakuan BIPM sebanyak 135 satuan ukuran. Untuk pelayanan laboratorium dalam BSN saat ini memberikan layanan sebanyak 388 lingkungan layanan kalibrasi. Jumlah sertifikat yang sudah dikeluarkan sebanyak 1157 per tahun untuk lebih dari 500 laboratorium.

\section{Akselerasi Pelayanan Standardidasi dan Penilaian Kesesuaian dalam Penanganan pandemi}

Meningkatnya kebutuhan akan standardiasi dan penilaian kesesuian sebagai akibat meningkatkan aktifitas dalam menangani pandemi COVID-19 dan adanya sistem protokol kesehatan selama pandemi, telah mendorong BSN melakukan percepatan pelayanan. Dalam hal pengembangan standar telah dilakukan proses percepatan perumusan standar, telekonferensi dalam perumusan standar (virtual) dan mengembangkan program perumusan SNI jalur mendesak. Dengan program ini kebutuhan stan- dar dari pemangku kepentingan dapat terlayani lebih cepat. Dalam bidang akreditasi percepatan pelayanan dilakukan dengan penerapan digital akreditasi, assesment jarah jauh (remote assessment) dan audit jarah jauh. Di samping percepatan proses pelayanan, juga dilakukan penerapan skema baru khususnya terkait dengan penerapan sistem manajemen biorisiko laboratorium. Demikian juga untuk layanan kalibrasi, juga dilakukan kalibrasi jarak jauh (remote calibration) dan dukungan analisis terhadap reka- man kalibrasi dari penguna jasa.

Untuk mendukung penerapan standar di rumah sakit, laboratorium medis dan juga LPK lain telah dilakukan penguatan SDM (capacity build- ing) pada 49 laboratorium uji dan laboratorium analisa alat kesehatan termasuk PCR (poly-merase chain reaction). Di samping itu juga telah dilakukan pembinaan dan pendampingan kepa- da 18 Usaha Mikro Kecil dan Menenga (UMKM) di bidang alatkesehatan.

\section{Tantangan Pengembangan standar untuk Pemulihan Ekonomi dan Kemandirian Nasional}

Berdasarkan pengalaman yang sangat berhaga dalam masa pandemi, maka untuk mempercepat pemulihan ekonomi, memperkuat daya saing dan kemandirian nasional maka peran standardisasi perlu diperkuat. Di antara yang paling krusial adalah ketersediaan standar yang mampu menjawab kebutuhan pasar, kebutuhan masyarakat dan perkembangan IPTEK nasional maupun global. Pengembangan standar dapat diarahkan antara lain untuk mendukung kemandirian bahan baku industri. Sekitar 30 persen impor nonmigas Indonesia berasal dari Tingkok, diantaranya yang paling besar adalah kelompok bahan baku dan bahan pendukung. Ketegantungan bahan baku industri telah memukul industri ketika terjadi pandemi. Standardisasi diperlukan untuk memberikan acuan pagi pemasok lokal dan juga untuk mendukung kemampuan berkompetisi dengan bahan baku impor. Memang diakui, bahwa pihak pengguna khususnya industri pengolahan masih memer- lukan waktu untuk penyesuaian dengan proses yang dimiliki dan kelayakan teknis lainnya ter- masuk keekonomiannya. Manfaat lain dari up- aya kemandirian bahan baku ini adalah ter- jadinya penciptakan rantai pasok baru, lapangan usaha, lapangan pekerjaan dan pada akhirnya dapat memperkuat struktur industri nasional. Kondisi ini juga akan mengundang peneliti dan pengembang teknologi untuk turut meneliti dan mengembangkan berbagai aspek produksi seperti proses, manufaktur, pengujian, pengembangan produk baru. Untuk mendukung upaya ini diperlukan data analisis terkait dengan kebutuhan industri dan data-data perkembangan impor bahan baku .

Pengembangan standar untuk alat kesehatan, obat-obatan dan penunjang kegiatan kebugaran juga tetap dikembangkan, sehingga ke depan kemandirian di bidang alat kesehatan dan obat obatan dapat ditingkatkan. Momentum pandemi adalah sangat baik karena telah terjadi banyak inovasi di bidang ini dan perlu terus ditumbuh kembangkan.

Untuk memperkuat ekonomi nasional, UMKM tetap menjadi perhatian, karena jumlahnya sangat besar yaitu sekitar 64 juta. UMK Mini di saat pandemi termasuk yang mendapat dampak terberat. Ini juga dirasakan di berbagai UMKM di dunia bahwa UMKM adalah usaha yang paling terdampak dari adanya krisis pandemi ini.

Dari sisi distribusi UMKM tersebar merata dan bidangnya usaha sangat beragam dan umumnya menggunakan potensi sumber daya lokal. Pengembangan standaruntuk mendukung UMKM sangat diiperlukan. Dukungan yang diperlukan antara lainadalah akses ke sumber informasi baik infromasi pasar, regulasi, tempat konsultasi dan pendampingan, insentif permodalan, penguatan kapasitas dalam penggunaan daring, pemanfaatan teknologi berbasis digital 
untuk pemasaran, komunikasi dengan mitra. Dalam pengembangan standar harus lebih difokuskan kepada potensi lokal yang cukup besar dan belum digarap secara optimal. Untuk diseminasi standardisasi, pengembangan Role Model UMKM masih relevan dan berdasarkan testimoni dinilai cukup efektif dalam penerapan standar. Dengan demikian anggapan bahwa standardisasi menjadi penghambat usaha mereka lambat laun akan dapat dihindari. Beberapa testimoni role model menyatakan bahwa manfaat dari penerapan standard antara lain adalah menjaga mutu yang berkelanjutan, meningkatkan efisiensi, mengurangi perolehan (mengurangi reject), memermudah akses pasar baik domestik (retail, E-Catalog, mengikuti tender terbuka) maupun ekspor, mengurangi biasa inspeksi dalam proses produksi, mendorong ter- jadinya inovasi.

Sejalan dengan program pemerintah dalammendorong inovasi, pengembangan standar juga harus mampu mendukung perkembangan inovasi. Penciptaan produk dan proses baru hasil riset dalam negeri. Inovasi harus didukung secara terintegrasi dengan standar dan sistem penilaian kesesuiannya untuk meningkatkan posisi jual produk inovasi. Inovasi yang terjadi di tanah air pada umumnya didorong olehkebutuhan masyarakat, perkembangan iptek dan pasar global. Namun demikian, beberapa inovasi terjadi karena perubahan perilaku masyakat atau pasar. Selama pandemi banyak pengamatan yang mengindikasikan bahwa telah terjadinya perilaku masyarakat akibat pandemi ini. Oleh karena itu, inovasi dan dukungan pengembangan standar perlu memperhatikan hal ini, sehingga proses hilirisasi semakin dapat diakselerasi.

\section{KESIMPULAN}

Pandemi COVID-19 telah merubah berbagai aspek kehidupan, tidak hanya menyangkut aspek kesehatan tetapi juga aspek ekonomi, sosial dan lingkungan. Berbagai kebijakan pemerintah telah dilakukan baik yang langsung terkait den- gan kesehatan, ataupun terkait dengan penan- gan dampak pandemi. Sejalan dengan kebijakan pemerintah yang sedang berjalan dan telah direncanakan, peran standardisasi dan penilaian kesesuaian untuk mendukung suksesnya program pemerintah sangat besar. Demikian juga peran pelayanan SPK untuk masyarakat dan dunia usaha sejalan dengan implementasi kebijakan pemerintah akan semakin meningkat. Peran ini dimulai dari dukungan terhadap penanganan pandemi baik terkait dengan peralatan medis, peralatan perlindungan diri, laboratorium yang kompeten dan pengujian laboratorum yang handal. Peran standardisasi dan peniliaian kesesuaian juga diarahkan pada proses pemulihan dampak semasa pandemi dan pemulihan pasca pandemi. Penangan di pasca pandemi diarahkan untuk meningkatkan kemandirian dan daya saing nasional. Untuk antisipasi ke depan Indonesia harus mengembangan sistem sendiri dalam menangani pandemi dan dampaknya, mengingat ada periodifikasi munculnya pandemi.

\section{DAFTAR PUSTAKA}

Avma, (2020). Guidelines for PPE use as veterinary facilities resume providing normal ser- vices. Retrieved Oktober 25, 2020 from https://www.avma.org/resourcestools/animal- health-and-welfare/COVID19/guidelines-ppe- COVID-19-pandemicdemand-exceeds

Chen J. (2020) Pathogenicity and transmissibility of 2019-nCoV-A quick overview and comparison with other emerging viruses. Microbes Infect 22:69-71. Retrieved Oktober 25, 2020 from https://doi.org/10.1016/ j.micinf.2020.01.004.

Dhama, K., Sharun, K., Tiwari, R., Sircar, S., Bhat, S., Malik, Y. S., ... \& RodriguezMorales, A. J. (2020). Coronavirus disease 2019-COVID-19.

ITC (International Trade Center.) (2020) COVID19: The Great Lockdown and its Impact on Small Business. Retrieved Okto- ber 28, 2020 from https://www.intracen.org/ SMEOutlook/

Kementerian Keuangan RI (The Minisitry of Finance of Rep. Indonesia). (2020). Kerangka Ekonomi Makro (KEM) dan PokokPokok Kebijakan Fiskal (PPKF) Tahun 2021 (Macroeconomic Framework (KEM) and Principles of Fiscal Policy (PPKF) in 2021. Retrieved September 25, 2020 from https://www.kemenkeu.go.id/publikasi/b erita/kem-ppkf-tahun-2021-skenarioapbn-menghadapi- tantangan-tahundepan/

(2020). Pres Conference Langkah Menghadapi COVID-19, 1 April 2020 (Pres Con- ference Steps to Face COVID-19, April 1, 2020)

Lee, K.H., Noh,J.\& Khim,J.S.(2020). The Blue Economy and the United Nations'sustainable development goals:Challenges and opportunities. Environment International 137 (2020) 105528

Lu H. (2020) Drug treatment options for the 
Peran Standardisasi Dan Penilaian Kesesuaian (SPK)

2019-new coronavirus (2019-nCoV).

Biosci Trends 14:69-71. Retrieved September 25, 2020 from https://doi.org/10.5582/bst.2020.010.

Ramful, K. 7Kieck, E. (2020). Standards: Life support for small businesses during COVID-19. Retrieved Oktober 18, 2020 from

https://www.intracen.org/covid19/Blog/

Standards-Life-support-for-small-

business- es-during-COVID-19/

Unido. (2020). Quality and Standards and their Role in Responding to COVID-19. Retrieved Oktober 18, 2020 from .https://www.unido.org/ sites/default/files/files/2020-04/.

Wang, C., Horby, P.W., Hayden, F.G. \& Gao, GF.
(2020). A novel coronavirus .outbreak of global health concern. Lancet 395:470 - 473. Retrieved Oktober 28, 2020 from https://doi.org/10.1016/S01406736(20)30185-9.

WHO. (2020). Corona virus dieses (COVID-19) outbreak : Right, Roles and Responsibilities of health worker, including key considera- tion for occupational safety and health. Retrieved Oktober 28, 2020 from https:// www.who.int/publications/i/item/coronavirus-disease-(COVID-19)-outbreakrights- roles-and-responsibilities-of-healthwork- ers-including-key-considerationsfor-occu- pational-safety-and-health 
